\title{
Comparison of leucine enkephalin and adrenocorticotrophin effects on adrenal function in fetal and adult sheep*
}

\author{
J. Bousquet, S. J. Lye and J. R. G. Challis $\dagger$
}

M.R.C. Group Reproductive Biology, The University of Western Ontario, Departments of Obstetrics and Gynaecology and Physiology, University Hospital, 339 Windermere Road, London, Ontario,

Canada N6A 5 A5

\begin{abstract}
Summary. At Day 120 125 of gestation equimolar amounts of ACTH and leuenkephalin injected in vivo provoked similar rises in plasma cortisol concentrations in chronically catheterized fetuses. There was no concomitant change in plasma DHEA concentrations, or in maternal cortisol concentrations. At term (Days 135-140) 2 out of 5 animals responded similarly to both leu-enkephalin and ACTH injections with a rise in plasma cortisol concentrations, but the other 3 animals, in which basal cortisol concentrations had already risen, showed no response to either agonist. In adult sheep, ACTH provoked a significant increase in the plasma cortisol concentrations, but equimolar amounts of leu-enkephalin were without effect. There was a significant output of cortisol in response to ACTH administration by collagenase-dispersed adrenal cells from term sheep fetuses in vitro. Leu-enkephalin had no effect on cortisol output from dispersed adrenal cells when added by itself, or with ACTH. We conclude that leu-enkephalin is able to function as a stimulator of pituitary-adrenal function during fetal life. The lack of effect of leu-enkephalin on adrenal cells implies that its action is exerted not directly at the adrenal gland, but indirectly at the level of the hypothalamus or pituitary through stimulation of the release of other corticotrophic substances.
\end{abstract}

\section{Introduction}

During pregnancy in some species, the placenta as well as the fetal pituitary synthesizes a variety of peptides that are structurally related to pro-opiomelanocortin (POMC; Liotta \& Krieger, 1980) or are presumably derived from pre-proenkephalin (Tan \& Yu, 1981). However, the functions of these peptides in mother and fetus are not entirely understood. Carson \& Challis (1982) have shown that leucine-enkephalin, injected into newborn lambs, provoked a rise in the concentration of cortisol in plasma in a dose-dependent fashion. Studies of adult rats have indicated that this effect might be mediated through the central release of adrenocorticotrophin (ACTH; De Souza \& Van Loon, 1982), although a direct effect on the adrenal itself cannot be excluded (Lymangrover, Dokas, Kong, Martin \& Saffran, 1981).

* Reprint requests to Dr J. R. G. Challis.

$\dagger$ Present address: St. Joseph's Hospital, Research Institute, University of Western Ontario, 268 Grosvenor Street, London, Ontario, Canada N6A 4V2. 
In the present study, we have extended our earlier observations (Carson \& Challis, 1982) to determine whether leucine-enkephalin influenced plasma cortisol concentrations during fetal life and in adult sheep. Since several studies have indicated that the responsiveness of the sheep fetal adrenal gland to ACTH stimulation rises in late pregnancy (Madill \& Bassett, 1973; Wintour et al., 1975), we compared the effects of equimolar bolus injections of leu-enkephalin with those of ACTH at two different times before parturition. We also measured changes in the plasma concentrations of dehydroepiandrosterone (DHEA), a potential oestrogen precursor which is secreted as its sulphoconjugate from the adrenal gland of the human fetus (Jaffe et al., 1981). In the present experiments, we measured free DHEA rather than its sulphoconjugate because the sheep fetal adrenal is reported to have relatively low sulpho-transferase activity (Anderson, Pierrepoint, Turnbull \& Griffiths, 1973). Finally, we initiated experiments to determine the site of action of leuenkephalin by examining its effects on cortisol output from fetal adrenal cells isolated from sheep fetuses near term.

\section{Materials and Methods}

In-tivo studies

Experiments were performed with 6 chronically catheterized fetal sheep. Under general anaesthesia (Challis \& Patrick, 1981) and using sterile techniques, catheters were implanted into the fetal carotid artery and jugular vein at Day 110-115 of pregnancy. Details of the catheterization procedures used have been published elsewhere (Challis \& Patrick, 1981).

All fetal experiments were begun 4-8 days after surgery. Studies were performed on the same fetuses at Days 120-125 and 135-140 of gestation. On successive days injections of $1 \mathrm{ml}$ sterile saline $(0 \cdot 154 \mathrm{M}-\mathrm{NaCl})$; adrenocorticotrophin 1-24 (Cortrosyn: Organon Ltd, Toronto, Canada; $10 \mu \mathrm{g}$ ); or leucine-enkephalin (Des-Tyr'-leucine enkephalin: Sigma, St Louis, MO, U.S.A; equimolar with the ACTH injection) were given through the jugular venous catheter. On each occasion, the saline test was conducted first, the order of ACTH and leu-enkephalin injection was randomized, and in some experiments a second control test with saline was given on Day 4. On each sampling day, samples of fetal blood $(1 \mathrm{ml})$ and maternal blood $(4 \mathrm{ml})$ were withdrawn at $-30,0$, $+10,+30$ and +60 min relative to the bolus injection of test substance, which was administered in $1 \mathrm{ml}$ saline. All blood samples were collected into heparinized tubes that were standing in ice. The samples were centrifuged at $1500 \mathrm{~g}$ for $10 \mathrm{~min}$ at $4^{\circ} \mathrm{C}$. The plasma was stored at $-20^{\circ} \mathrm{C}$ until subsequent analysis.

Experiments were performed in 6 non-pregnant sheep during anoestrus. Under general anaesthesia vinyl catheters were introduced into the femoral artery and femoral vein as described previously. The experimental design was as described for the fetuses but using 10 -fold greater amounts of $\mathrm{ACTH}_{1-24}$ and leu-enkephalin. Injections were made through the femoral vein catheter. Blood samples $(5 \mathrm{ml})$ were withdrawn from the femoral arterial catheter at the same time intervals as in the fetal experiments.

\section{In-vitro studies}

In the pregnant sheep, intrauterine pressure was monitored continuously from an intraamniotic catheter (Challis \& Patrick, 1981). Signals from the pressure transducer were amplified to record continuously on a Grass Model 78 polygraph with a scale set from 0 to $100 \mathrm{mmHg}$. The appearance of Type B labour-like contractions (Lye, Sprague, Mitchell \& Challis, 1983) of amplitude greater than $10 \mathrm{mmHg}$ were indicative of early labour. At this time, general anaesthesia was induced by intravenous pentobarbitone sodium (Abbott, Montreal, Quebec). The fetuses were removed rapidly and weighed. The fetal adrenal glands were dissected out, cleaned, weighed and dispersed into single cell suspensions using $0.05 \%$ collagenase as described previously 
(Glickman \& Challis, 1980). Fetal adrenal cells were counted and were diluted to a concentration of 100000 cells $/ \mathrm{ml}$ in Krebs-Ringer bicarbonate buffer (Dawson, Elliott, Elliott \& Jones, 1969). The cells were added to plastic tubes containing various amounts of $\mathrm{ACTH}_{1-24}$, leucine-enkephalin or combinations of ACTH and leucine-enkephalin, to give a final concentration of $50000 \mathrm{cells} / \mathrm{ml}$. The cells were incubated for $4 \mathrm{~h}$ at $37^{\circ} \mathrm{C}$ under $95 \% \mathrm{O}_{2}-5 \% \mathrm{CO}_{2}$ and the incubations were stopped by freezing. Cell viability at the beginning, and in some experiments at the end, of the incubation period was assessed by the exclusion of trypan blue stain, and was consistently greater than $95 \%$.

\section{Radioimmunoassay}

Cortisol was measured by radioimmunoassay using an antibody raised in our laboratory, and employing procedures that have been evaluated with respect to fetal and maternal sheep plasma, and incubation media from isolated adrenal cells (Glickman \& Challis, 1980; Challis et al., 1981). The intra- and inter-assay coefficients of variation were 7.8 and $8.0 \%$ respectively. Dehydroepiandrosterone (DHEA) was measured using an antibody and radioimmunoassay procedure as reported previously (Challis, Socol, Murata, Manning \& Martin, 1980). The recovery of known amounts of DHEA added to fetal plasma was $y=0.91 x+7.2$ where $y=$ amount added and $x=$ amount recovered. All DHEA samples were measured in one assay. The intra-assay coefficient of variation was $8.9 \%$.

\section{Statistical analysis}

Throughout the text all results are presented as means \pm s.e.m. for the number of observations indicated. For the purposes of analysis the mean basal concentration of steroid in plasma was calculated from the value at $-30 \mathrm{~min}$ and in the $0 \mathrm{~min}$ sample. We used two-way unbalanced analysis of variance and Duncan's Multiple Range Test to determine the effects of treatment and of time on cortisol concentrations in plasma or incubation media.

\section{Results}

\section{In-vivo studies}

Fetuses at Day 120-125. The mean basal cortisol concentration in fetuses at 120-125 days of gestation was $5 \cdot 37 \pm 1.55 \mathrm{ng} / \mathrm{ml}(\mathrm{N}=6)$. There was no effect of saline injection on plasma cortisol concentrations. There was a significant increase in plasma cortisol concentrations at $+10 \mathrm{~min}$ after injection of ACTH or leu-enkephalin. The differences in mean cortisol concentrations at +30 and +60 min were not statistically significant $(P>0.05)$. The increment $(\Delta)$ in plasma cortisol after each of these two agonists was similar (Text-fig. 1a). The mean basal cortisol concentration had risen to $10 \cdot 25 \pm 3.33 \mathrm{ng} / \mathrm{ml}(\mathrm{N}=6)$ at the start of the second saline injection. Again, the saline had no significant effect on plasma cortisol concentrations, values being $12 \cdot 45 \pm 3 \cdot 10 \mathrm{ng} / \mathrm{ml}$ at +10 $\min , 7.65 \pm 2.79 \mathrm{ng} / \mathrm{ml}$ at $+30 \mathrm{~min}$ and $4.78 \pm 1.58 \mathrm{ng} / \mathrm{ml}$ at $+60 \mathrm{~min}$.

In contrast to the effects on plasma cortisol, there were no significant effects of any treatment on plasma DHEA concentrations at Days 120-125. In the pre-injection samples the concentration of DHEA was $2-3 \mathrm{ng} / \mathrm{ml}$, and the values fluctuated around $2 \mathrm{ng} / \mathrm{ml}$ for the duration of the study (Textfig. 1b).

Maternal cortisol concentrations varied between 5 and $10 \mathrm{ng} / \mathrm{ml}$. There was no significant effect on the maternal plasma cortisol concentration after administration of saline, ACTH or leuenkephalin to the fetus (data not shown).

Fetuses at Day 135-140. The response (increment) in plasma cortisol after administration of ACTH or leu-enkephalin to fetuses later in gestation appeared to vary according to the basal cortisol concentration. There were no significant effects of leu-enkephalin or ACTH when the 


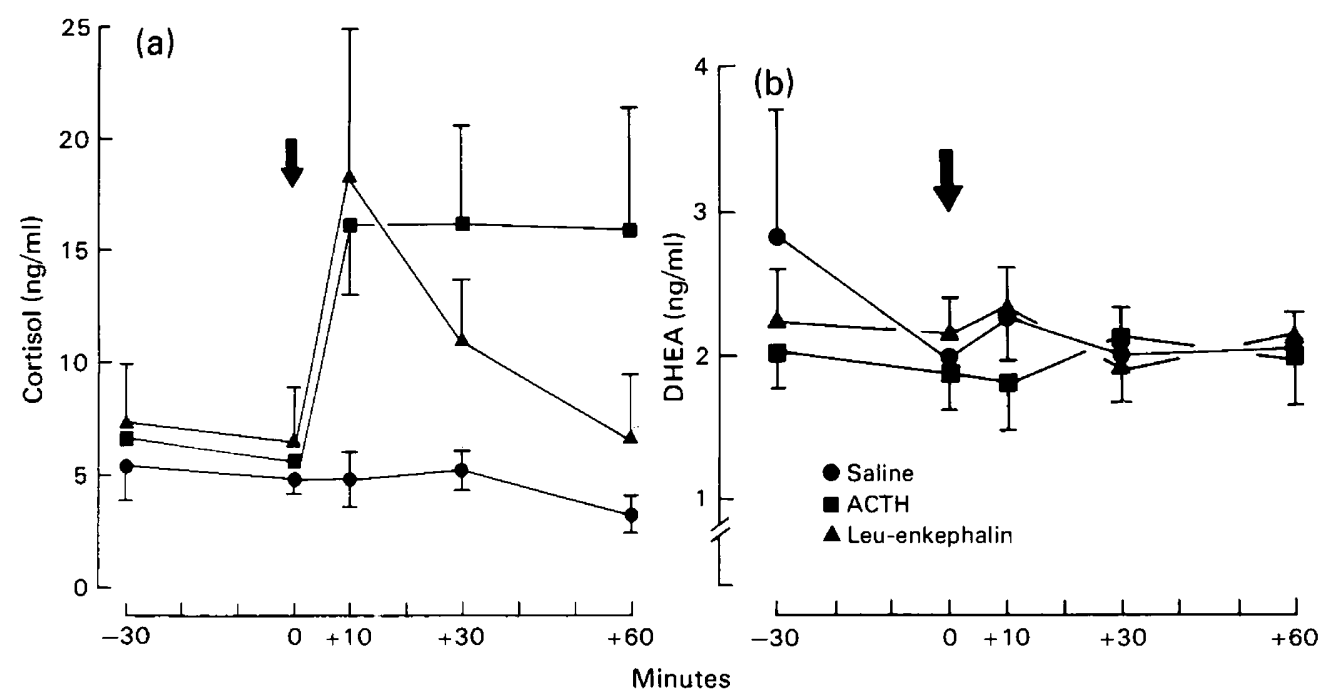

Text-fig. 1. The concentrations of (a) cortisol and (b) dehydroepiandrosterone in the plasma of chronically catheterized fetal sheep after bolus injection at time 0 of $\mathrm{ACTH}_{1-24}$, leucineenkephalin or saline. Each value is the mean \pm s.e.m. for observations on 6 fetuses at Day 120 125 of pregnancy.

cortisol concentrations for all the fetuses in each group were combined. However, it was noticeable that, in 2 fetuses in which the basal cortisol concentration ranged between 20 and $40 \mathrm{ng} / \mathrm{ml}$, there were increments in plasma cortisol of $20-30 \mathrm{ng} / \mathrm{ml}$ after ACTH or leu-enkephalin administration. In 3 different fetuses estimated to be $<24 \mathrm{~h}$ before delivery, in which the basal cortisol concentrations fluctuated between 50 and $120 \mathrm{ng} / \mathrm{ml}$, there was no obvious change in the plasma cortisol concentration after the injection of either agonist (Text-fig. 2).

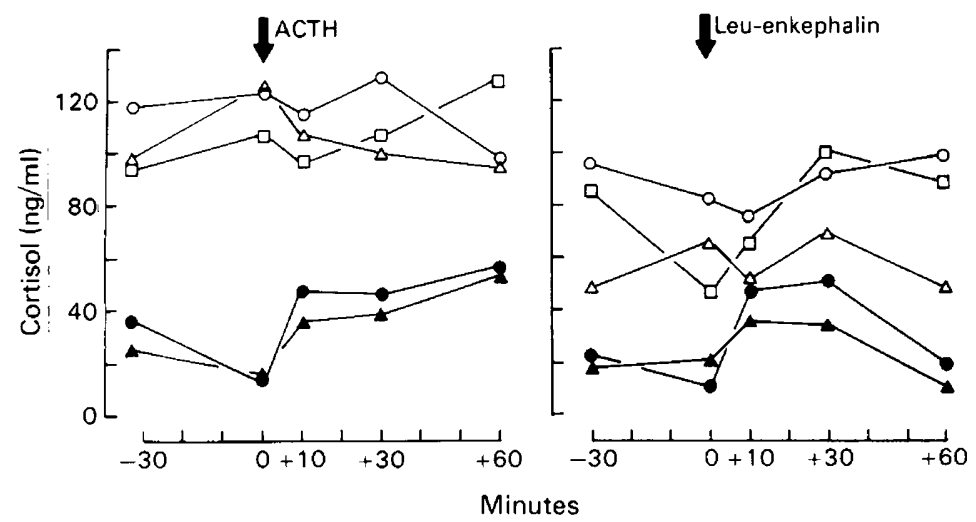

Text-fig. 2. The effect of equimolar $\mathrm{ACTH}_{1-24}$ or leucine-enkephalin on the concentration of cortisol in the plasma of 5 individual sheep fetuses in late pregnancy. Two fetuses with basal cortisol concentrations of $20-40 \mathrm{ng} / \mathrm{ml}(\boldsymbol{O}, \Delta)$ responded to both agonists, whereas 3 fetuses with basal cortisol concentrations of $50-120 \mathrm{ng} / \mathrm{ml}(\square, \bigcirc, \triangle)$ did not respond.

The mean concentration of DHEA in fetal plasma on Days $135-140$ was $2 \cdot 01 \pm 0 \cdot 19 \mathrm{ng} / \mathrm{ml}$ $(\mathrm{N}=6)$. There was no significant effect of any treatment on fetal DHEA concentrations at this time (data not shown). 
Adult sheep. The mean pre-injection concentration of cortisol in the adult sheep was $11.05 \pm$ $2.32 \mathrm{ng} / \mathrm{ml}(\mathrm{N}=6)$. There was no significant change in the plasma cortisol concentration after saline or leu-enkephalin injection. However, equimolar injection of ACTH produced a significant increase in plasma cortisol concentration, with an increment of $80-90 \mathrm{ng} / \mathrm{ml}$ (Text-fig. 3).

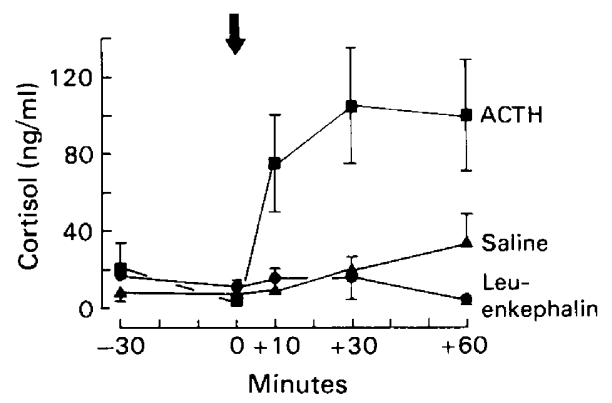

Text-fig. 3. The effect of $\mathrm{ACTH}_{1-24}$, leucine-enkephalin or saline on plasma cortisol concentrations in adult anoestrous sheep. Each value is the mean \pm s.e.m. for observations on 6 animals.

\section{In-vitro adrenal responses}

Collagenase-dispersed adrenal cells prepared from term fetal sheep produced a significant increase in cortisol output in response to ACTH treatment in vitro (Text-fig. 4). On average, the increment was $1.89 \mathrm{ng} / 50000$ cells for $4 \mathrm{~h}$. There was no significant response of the cells in terms of cortisol output to leucine-enkephalin. In two experiments, each performed in duplicate, ACTH dose-response curves were performed in the presence of fixed amounts of leu-enkephalin $(0 \cdot 3 \times$ $10^{-10}$ and $\left.30 \times 10^{-10} \mathrm{M}\right)$. Addition of leu-enkephalin did not influence the ability of the cells to secrete cortisol in response to ACTH stimulation.

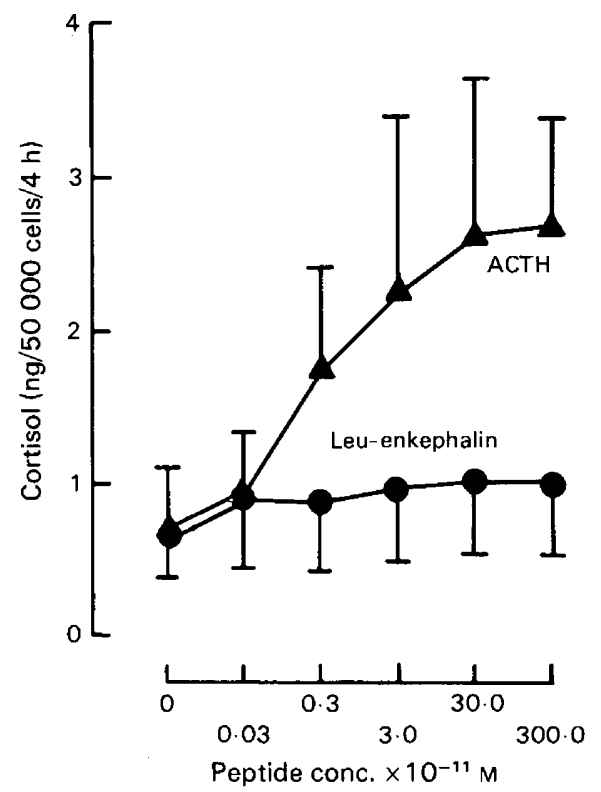

Text-fig. 4. The output of cortisol by dispersed adrenal cells, from term fetal sheep, incubated with $\mathrm{ACTH}_{1-24}(\boldsymbol{\Lambda})$ or leucine-enkephalin $(\bullet)$. Each value is the mean \pm s.e.m. for observations on 4 fetuses. 


\section{Discussion}

Bolus injections of equimolar amounts of $\mathrm{ACTH}_{1-24}$ or leucine-enkephalin both provoked a significant increase in the plasma cortisol concentration in fetal sheep at Day 120-125 of gestation. In fetuses nearer term (Days 135-140), when basal cortisol concentrations had risen, two response patterns emerged. In 2 out of 5 animals, $>48 \mathrm{~h}$ before labour, both agonists stimulated a similar rise in plasma cortisol, indicating no selective change in fetal adrenal response to their effects during late pregnancy. However, in 3 out of 5 fetuses, $<48 \mathrm{~h}$ before parturition, there was no response to either ACTH or leu-enkephalin. Basal cortisol concentrations in these fetuses were higher, and it might be suggested that the adrenal was already secreting cortisol maximally in response to endogenous ACTH, which is known to be rising at this time (Rees, Jack, Thomas \& Nathanielsz, 1975; Jones, 1983). This finding is consistent with the loss in minute-to-minute variability in the plasma cortisol concentration of fetuses during the last 4-5 days before parturition (Challis et al., 1981). A similar poor response to exogenous ACTH is seen in lambs at $4 \mathrm{~h}$ of age, in which basal cortisol concentrations are also high (Carson \& Challis, 1981).

We found no change in the maternal cortisol concentration associated with fetal leu-enkephalin or ACTH injections. This finding is consistent with the lack of transplacental transfer of these peptides (Jones, Luther, Ritchie \& Worthington, 1975), and suggests a lack of effect of leuenkephalin administration to the fetus on the secretion of biologically active corticotrophic substances into the maternal compartment.

The response pattern of adult sheep to equimolar injections of ACTH or leu-enkephalin was different from that of the fetuses. In adult animals, ACTH, but not leu-enkephalin, provoked a rise in the concentration of cortisol in plasma, suggesting that the leu-enkephalin response is peculiar to fetuses and neonatal sheep (Carson \& Challis, 1982), but is lost some time thereafter. These results raised the question of the site of action of leu-enkephalin on the adrenal response.

To examine this issue, we incubated adrenal cells from fetal sheep with ACTH or leuenkephalin. Although these cells were responsive to ACTH, they did not respond significantly to leu-enkephalin over the concentration range studied, nor in two experiments did leu-enkephalin influence the response pattern to ACTH. There are several possible explanations for these results. It is conceivable that the fetal adrenal response to leu-enkephalin changes with gestational age, and term fetal adrenals may have been inappropriate for this study. However, the in-vivo results in the present experiments, and our previous results for newborn lambs (Carson \& Challis, 1982), indicated that term fetal adrenals should have responded to leu-enkephalin if the effect was a direct one. We cannot exclude the possibility that our digestion procedures destroyed adrenal leuenkephalin receptors. However the mild nature of the digestion procedure and the significant response of the fetal adrenal cells to ACTH would seem to negate this suggestion. In superfused rat adrenocortical tissue, methionine enkephalin produced a greater effect in potentiating the stimulation of corticosteroid output by a subsequent challenge with ACTH than it did as a direct corticotrophic agonist (Lymangrover et al., 1981). However, in the present study, leu-enkephalin was equally devoid of activity when given by itself or concomitantly with ACTH.

These findings contrast with several reports showing direct effects of opioids on adrenal function. In contrast to the results of Lymangrover et al. (1981), others have shown that morphine decreases the ACTH responsiveness of rat adrenals. High concentrations of $\beta$-endorphin stimulated corticosterone output from isolated rat adrenal cells, although with a potency less than $2 \%$ that of ACTH (Shanker \& Sharma, 1979), whereas lower concentrations of $\beta$-endorphin inhibited ACTH-stimulated or basal corticosterone output (Szalay \& Stark, 1981). Racz et al. (1980) reported that methionine-enkephalin and leucine-enkephalin suppressed corticosterone output by rat adrenal tissue in vitro.

A further possible explanation for the discrepancy between our in-vivo and in-vitro results, and perhaps for the change in response in adult sheep, is that in fetuses and newborns (Carson \& Challis, 1982) leu-enkephalin acts at the hypothalamus or pituitary to provoke the release of ACTH 
or other corticotrophic agents. De Souza \& Van Loon (1982) reported a significant rise in plasma ACTH concentrations in rats, 5-10 min after administration of the potent enkephalin analogue $D^{-}$ ala $^{2}$-met-enkephalinamide. Hypophysectomy or pre-treatment with dexamethasone blocked the increase in corticosterone after analogue administration, supporting strongly the suggestion of an intermediary role of $\mathrm{ACTH}$ release in the corticosteroid response. These results are consistent with studies showing an increase in plasma corticosterone concentrations in mice after intracerebroventricular administration of methionine-enkephalin (Gibson, Ginsburg, Hall \& Hart, 1979), and support a hypothalamic site of action for the opiate. The further possibility that growth hormone is released after leu-enkephalin injection (Dupont, Cusan, Labrie, Coy \& Li, 1977) and stimulates the fetal adrenal in vivo (Devaskar, Devaskar, Voina, Velayo \& Sperling, 1981) cannot be excluded at present.

If the major site of leu-enkephalin action is at the hypothalamus, then the peptide has to cross the blood-brain barrier to exert its effect. Partridge \& Mietus (1981) found that enkephalins have low permeability across the blood-brain barrier of the cow, and that the capillaries in this species had high enkephalinase activity. It is possible that the loss of leu-enkephalin effect compared to ACTH in adult sheep over that found in fetuses is associated with decreased permeability and with increased enkephalinase activity at the blood-brain barrier in the adult.

We have been unable to demonstrate changes in the concentration of DHEA in fetal plasma after administration of leu-enkephalin at 120-125 or 135-140 days of pregnancy. These results are consistent with observations suggesting that the fetal adrenal is not a major source of $\mathrm{C}_{19}$ steroids during late pregnancy (Flint, Anderson, Steele \& Turnbull, 1975).

At present, we can only speculate on the physiological significance of our results. The identity of the trophic hormone(s) to the ovine fetal adrenal gland remains unclear. In other species, enkephalins are synthesized in placental (Tan \& Yu, 1981) and adrenal medulla (Wilson, Chang \& Viveros, 1980) tissue. The present study raises the possibility that, if isolated in the sheep fetus, enkephalins may function as neurotransmitters and be implicated in the regulation of pituitaryadrenal function during fetal life.

We thank Ms Cher Sprague for technical assistance, and Mr Doug Johnston for providing sheep at known stages of pregnancy. This work was supported by the Canadian Medical Research Council (Group Grant in Reproductive Biology, J.R.G.C; Fellowship, S.J.L.) and by grants from the Jean and Richard Ivey Fund, and the Physicians' Services Inc., of Ontario to J.R.G.C. and Dr J. E. Patrick.

\section{References}

Anderson, A.B.M., Pierrepoint, C.G., Turnbull, A.C. \& Griffiths, K. (1973) Steroid investigations in the developing sheep fetus. In The Endocrinology of Pregnancy and Parturition, pp. 23-39. Ed. C. G. Pierrepoint. Alpha Omega, Cardiff.

Carson, G.D. \& Challis, J.R.G. (1981) Adrenal responses to prostaglandin $\mathrm{E}$ in newborn lambs. Am. J. Obstet. Gynec. 139, 359-363.

Carson, G.D. \& Challis, J.R.G. (1982) Changes in plasma cortisol and progesterone after administration of enkephalins to newborn lambs. Can. J. Physiol. Pharmacol. 60, 1166-1170.

Challis, J.R.G. \& Patrick, J.E. (1981) Fetal and maternal oestrogen concentrations throughout pregnancy in the sheep. Can. J. Physiol. Pharmacol. 59, 970-978.

Challis, J.R.G., Socol, M., Murata, Y., Manning, F.A. \& Martin, C.B., Jr (1980) Diurnal variations in maternal and fetal steroids in pregnant rhesus monkeys. Endocrinology 106, 1283-1288.
Challis, J.R.G., Patrick, J.E., Cross, J., Workewych, J.V., Manchester, E.L. \& Power, S. (1981) Short-term fluctuations in the concentration of cortisol and progesterone in fetal plasma, maternal plasma and amniotic and allantoic fluids from sheep during late pregnancy. Can. J. Physiol. Pharmacol. 59, 261267.

Dawson, R.M.C., Elliott, D.C., Elliott, W.H. \& Jones, K.M. (1969) Data for Biochemical Research. Oxford University Press.

De Souza, E.B. \& Van Loon, G.R. (1982) D-Ala²-Metenkephalinamide, a potent opioid peptide, alters pituitary-adrenocortical secretion in rats. Endocrinology 111, 1483-1490.

Devaskar, U.P., Devaskar, S.U., Voina, S., Velayo, N. \& Sperling, M.A. (1981) Growth hormone stimulates adrenal steroidogenesis in the fetus. Nature, Lond. 290, 404-405.

Dupont, A., Cusan, L., Labrie, F., Coy, D.G. \& Li, C.H. 
(1977) Stimulation of prolactin release in the rat by intraventricular injection of beta-endorphin and methionine enkephalin. Biochem. Biophys. Res. Commun. 75, 76-82.

Flint, A.P.F., Anderson, A.B.M., Steele, P.A. \& Turnbull, A.C. (1975) The mechanism by which foetal cortisol controls the onset of parturition in the sheep. Biochem. Soc. Trans. 3, 1189-1194.

Gibson, A., Ginsburg, M., Hall, M. \& Hart, S.L. (1979) The effect of intracerebroventricular administration of methionine-enkephalin on the stress-induced secretion of corticosterone in mice. Br.J. Pharmacol. 66, 164-166.

Glickman, J.A. \& Challis, J.R.G. (1980) The changing response pattern of sheep fetal adrenal cells throughout the course of gestation. Endocrinology 106, 13711376.

Jaffe, R.B., Seron-Ferre, M., Crickard, K., Koritnik, D., Mitchell, B.F. \& Huhtaniemi, I.T. (1981) Regulation and function of the primate fetal adrenal gland and gonad. Recent Prog. Horm. Res. 37, 41-96.

Jones, C.T. (1983) The integration of adrenal and pituitary activity during development. In Initiation of Parturition: Prevention of Prematurity, pp. 17-23. Eds P. C. MacDonald \& J. Porter. Ross Laboratories, Columbus.

Jones, C.T., Luther, E., Ritchie, J.W.K. \& Worthington, D. (1975) The clearance of ACTH from the plasma of adult and fetal sheep. Endocrinology 96, 231-234.

Liotta, A.S. \& Krieger, D.T. (1980) In vitro biosynthesis and comparative posttranslational processing of immunoreactive precursor corticotropin $/ \beta$-endorphin by human placenta and pituitary cells. Endocrinology 106, 1504-1511.

Lye, S.J., Sprague, C.L., Mitchell, B.F. \& Challis, J.R.G. (1983) Activation of ovine fetal adrenal function by pulsatile or continuous administration of adrenocorticotropin-(1-24). I. Effects on fetal plasma corticosteroids. Endocrinology 113, 770-776.

Lymangrover, J.R., Dokas, L.A. Kong, A., Martin, R. \&
Saffran, M. (1981) Naloxone has a direct effect on the adrenal cortex. Endocrinology 109, 1132-1137.

Madill, D. \& Bassett, J.M. (1973) Corticosteroid release by adrenal tissue from fetal and newborn lambs in response to corticotrophin stimulation in a perifusion system in vitro. J. Endocr. 58, 75-87.

Partridge, W.M. \& Mietus, L.J. (1981) Enkephalin and blood-brain barrier: studies of binding and degradation in isolated brain microvessels. Endocrinology 109, 1138-1143.

Racz, K., Glaz, E., Kiss, R., Lada, G., Varga, I., Vida, S., Di Gleva, K., Medzihradsky, K., Lichtwald, K. \& Veosei, P. (1980) Adrenal cortex - a newly recognized peripheral site of action of enkephalins. Biochem. Biophys. Res. Commun. 97, 1346-1353.

Rees, L.H., Jack, P.M.B., Thomas, A.L. \& Nathanielsz, P.W. (1975) Role of foetal adrenocorticotrophin during parturition in sheep. Nature, Lond. 253, 274 275.

Shanker, G. \& Sharma, R.K. (1979) $\beta$-Endorphin stimulates corticosterone synthesis in isolated rat adrenal cells. Biochem. Biophys. Res. Commun. 86, $1-5$.

Szalay, K. \& Stark, E. (1981) Effect of beta-endorphin on the steroid production of isolated zona glomerulosa and zona fasciculata cells. Life Sci. 29, 1355-1361.

Tan, L. \& Yu, P.H. (1981) De novo biosynthesis of enkephalins and their homologues in the human piacenta. Biochem. Biophys. Res. Commun. 98, 752760.

Wilson, S.P., Chang, K.-J. \& Viveros, O.H. (1980) Synthesis of enkephalins by adrenal medullary chromaffin cells: reserpine increases incorporation of radiolabelled amino acids. Proc. natn. Acad. Sci. U.S.A. 77, 4364-4368.

Wintour, E.M., Brown, E.H., Denton, D.A., Hardy, K.J., McDougall, J.G., Oddie, C.H. \& Whipp, G.T. (1975) The ontogeny and regulation of corticosteroid secretion by the ovine fetal adrenal. Acta endocr., Copenh. 79, $30 \mathrm{l}-316$.

Received 5 July 1983 